\title{
Changes in the morphology of porous anodic films formed on aluminium in natural and artificial ageing
}

\author{
V. López", E. Otero*, A. Bautista*, E. Escudero* and J.A. González*
}

\begin{abstract}
Transmission electron microscopy and electrochemical impedance spectroscopy are used to demonstrate that the water retained in porous anodic aluminium oxide films is the main reason for their reactivity under electron beam irradiation in the TEM, accelerated ageing in an oven at $100^{\circ} \mathrm{C}$, or natural ageing over months and years in an outdoor atmosphere. Though the kinetics in each medium are highly different, there is a clear similarity between the structural and physical-chemical transformations that take place. Unsealed layers, practically free of water, hardly change their structure under the effect of electron beams and show the same impedance plots after hours at $100{ }^{\circ} \mathrm{C}$ or after years at environmental temperature in dry atmospheres.
\end{abstract}

Keywords Anodised aluminium. Sealing. Ageing. Transmission electron microscopy. Electrochemical impedance spectroscopy.

\section{Cambios en la morfología de las capas anódicas porosas de óxido de aluminio durante el envejecimiento en ambientes naturales y artificiales}

\begin{abstract}
Resumen La microscopía electrónica de transmisión, por una parte, y la espectroscopia de impedancia electroquímica, por otra, demuestran que el agua retenida en las películas anódicas porosas de óxido de aluminio es la principal responsable de su reactividad bajo la irradiación del haz de electrones en el MET, en el envejecimiento acelerado en la estufa a $100{ }^{\circ} \mathrm{C}$ o en el envejecimiento natural de meses y años en la atmósfera a temperatura ambiente. Aunque, de cinéticas muy diferentes, existe una indudable semejanza entre las transformaciones estructurales y físico-químicas que tienen lugar en los tres medios. Las capas sin sellar, prácticamente exentas de agua, apenas cambian su estructura por efecto del haz de electrones y muestran los mismos diagramas de impedancia después de horas a $100{ }^{\circ} \mathrm{C}$ o de años a temperatura ambiente en atmósferas secas.
\end{abstract}

Palabras clave Capas anódicas. Aluminio. Morfología de las capas. Subestructura. Microscopía electrónica de transmisión.

\section{INTRODUCTION}

Scanning electron microscopy (SEM), and especially transmission electron microscopy (TEM), are the techniques that have contributed most to knowledge of the structure of anodic films formed on aluminium and its alloys ${ }^{[1-7]}$. Thus it is known that in chromic, phosphoric, oxalic and sulphuric acid solutions, those most widely used in practice, especially the latter, coatings are formed with two stratas: the barrier and porous layers. The former, in direct contact with the metal, is continuous, compact and of very low thickness, $10-14 \AA \cdot V^{[6]}$. The outer layer has a honeycomb structure of hexagonal cells, each with a central pore perpendicular to the substrate surface. The dimensions of the cells and pores depend essentially on the anodising bath and on the voltage applied ${ }^{[2 \text { and } 7]}$.

TEM observation presents the disadvantage that the electron beam alters the substructure of anodic films, more intensely and rapidly the greater their water content and contamination with anions from the anodising bath ${ }^{[1}$ and $\left.3-5\right]$. Nevertheless, it continues to be an unmatched tool for studying the effect of any variable in anodising and sealing processes on the structure and quality of oxide films.

$\left(^{*}\right.$ Centro Nacional de Investigaciones Metalúrgicas (CENIM), (CSIC), Avda. Gregorio del Amo, 8. 28040 Madrid (España). 
The present work aims to explore the possible parallelism between structural modifications caused by the electron beam and those experienced by anodic films during artificial ageing in an oven or during much longer periods in natural environments.

\section{MATERIALS AND EXPERIMENTAL METHODS}

\subsection{Materials}

As in previous studies ${ }^{[8}$ and 9$]$, use was made of aluminium specimens of commercial purity $(99.5$ $\%)$, of $5 \times 10 \mathrm{~cm}$, anodised under technical conditions in a sulphuric acid solution $(18 \%)$ at 20 ${ }^{\circ} \mathrm{C}$, at a current density of $1.5 \mathrm{~A} / \mathrm{dm}^{2}(15-16 \mathrm{~V})$, for $45 \mathrm{~min}$. Once anodised, the specimens were repeatedly rinsed in running water and finally dried with pressurised air. The thickness of the oxide layers was $20 \pm 1 \mu \mathrm{m}$ and they were subjected to different sealing times. Consideration was also made of other specimens anodised in the same conditions and exposed for many years in the natural testing station situated on the roof terrace at CENIM. A further series of specimens were anodised in a $4 \%$ oxalic acid bath, applying a voltage of $40 \mathrm{~V}$, with the aim of comparing their morphology with that of the anodic layers formed in sulphuric acid baths.

\subsection{Tests performed}

Impedance diagrams were obtained for the anodised specimens, sealed and unsealed, immediately after their manufacturing and after different ageing times, in some cases up to several years $^{[8}$ and 9$]$. The surface area exposed to the solution in the impedance tests was $1 \mathrm{~cm}^{2}$, using a frequency range of $1 \mathrm{mHz}$ to $100 \mathrm{kHz}$ and the same equipment and test cell set-up previously employed.

Once separated from the metallic substrate, by dissolution of the latter in a mercury chloride solution, the anodic layers were subjected to transmission electron microscopy studies.

The appropriate thicknesses for observing the specimens in the TEM were achieved by ionic thinning. As the ion beam acted on both faces, the cross sections of the cells and pores correspond, approximately, to the centre of the anodic films. Micrographs were obtained for sealed and unsealed anodic layers, recently formed and after several years of atmospheric exposure. The microstructure was also determined for a recently sealed specimen after artificial ageing for $24 \mathrm{~h}$ in an oven at $100^{\circ} \mathrm{C}$. The films obtained in oxalic acid solutions, both sealed and unsealed, were observed without any type of prior ageing.

\section{RESULTS}

TEM observation of the unsealed layer (Figs. 1a and $1 \mathrm{~b}$ ) precisely defines an almost circular pore profile, with a well ordered geometric dispersion, that can be attributed to the general structure of hexagonal cells with a central pore accepted by all researchers. The cell wall material contains hardly any water, yielding only $0.3 \%$ of its weight when heated for $24 \mathrm{~h}$ at $200^{\circ} \mathrm{C}$. As can be seen in the figures, it is reasonably stable, with no alterations of importance being detected during the first ten minutes of exposure to the TEM electron beam.

Figures $2 \mathrm{a}$ and $2 \mathrm{~b}$ show sections parallel to the surface plane of an anodised specimen treated with traditional hydrothermal sealing (THS) for $45 \mathrm{~min}$ in boiling deionised water, after different electron beam exposure times. Great instability of the coating is seen, with very fast transformations that start in the pore fill material and cause homogenization of all the section of hexagonal cells in a matter of minutes.

With specimens sealed in boiling water and aged for 17 years in the Madrid atmosphere, the evolution of the oxide layer towards a stable homogenous product seems to be even more advanced, as is indicated by the smaller difference in contrast between the pore fill material and the cell wall material (Fig. 3).

A similar structure is observed in the coating sealed in boiling deionised water and artificially aged by heating in an oven for $24 \mathrm{~h}$ at $100{ }^{\circ} \mathrm{C}$ (Fig. 4).

Figures $5 \mathrm{a}$ and $5 \mathrm{~b}$ display TEM images corresponding to anodic films obtained in an oxalic acid bath, for electron beam exposure times of 0 and 4 minutes, respectively. Very dark bands of contrast are observed at the cell limits. The cell walls appear in a grey tone, in which a substructure is suggested that is clearly resolved with longer exposure to the electron beam. The pore limit is defined by a much lighter contrast, with the alternation of nanocrystals and nanopores of 1-3 $\mathrm{nm}$ in size. With irradiation there is a progressive homogenisation across the entire section of the cell, except for the limit bands.

The impedance diagrams in figure 6 correspond to an unsealed anodised film and another sealed for 

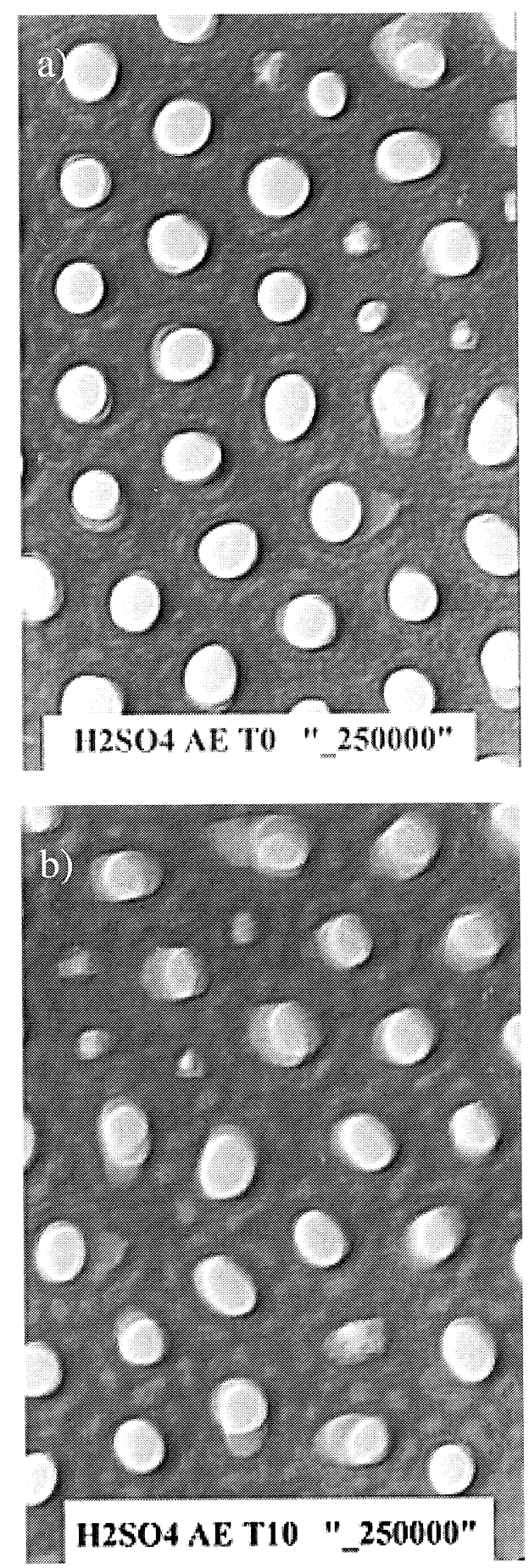

Figure 1. Micrographs of a section parallel to the surface plane of an unsealed anodic film, ionically thinned, for different electron beam exposure times: a) 0 min and b) 10 $\min$.

Figura 1. Micrografías de una sección paralela al plano de la superficie de un anodizado sin sellar, adelgazado iónicamente, para distintos tiempos de exposición al haz de electrones: a) $0 \mathrm{~min}$ y b) $10 \mathrm{~min}$.

$45 \mathrm{~min}$ in boiling deionised water, before and after artificial ageing in an oven for $24 \mathrm{~h}$ at $100^{\circ} \mathrm{C}$. For comparative purposes, a diagram is also included for an anodic film sealed for $45 \mathrm{~min}$ after 5 years of
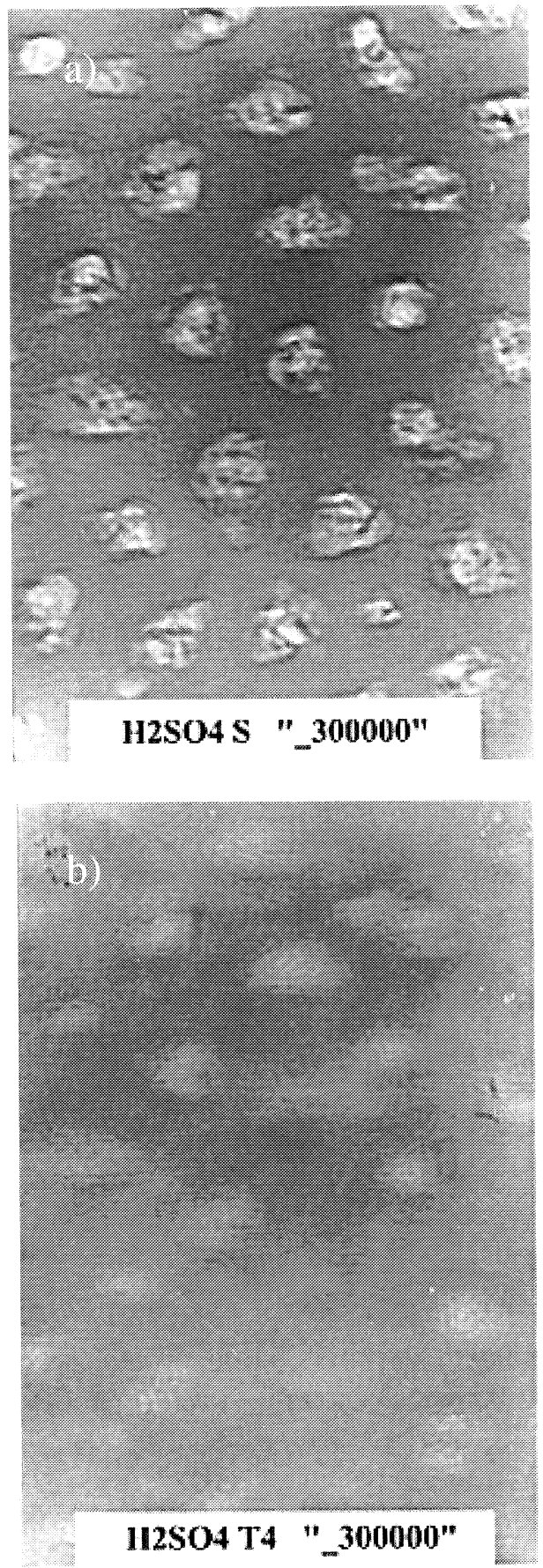

Figure 2. TEM micrographs obtained in the same conditions as figure 1 but for a film with a THS of $45 \mathrm{~min}$ in boiling deionised water: a) $0 \mathrm{~min}$ and b) $4 \mathrm{~min}$.

Figura 2. Micrografías obtenidas con el MET, en las mismas condiciones que la figura 1 , pero para una película con un SHT tradicional de $45 \mathrm{~min}$ en agua desionizada a ebullición: a) 0 min y b) $4 \mathrm{~min}$.

natural ageing in the Madrid atmosphere. It can be seen that artificial and natural ageing lead to similar electrochemical characteristics of the anodic oxides, though in very different time periods. 


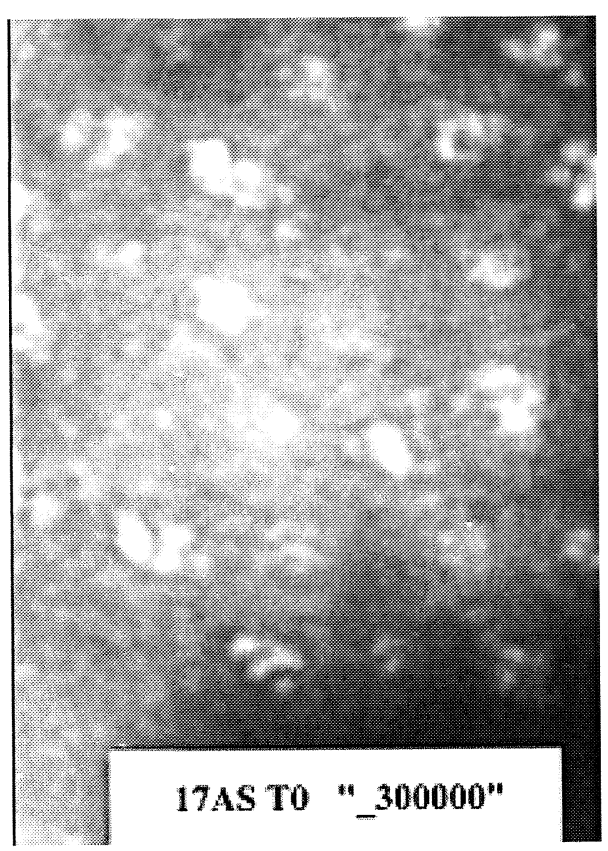

Figure 3. Micrograph of the structure of a film sealed for 45 min in boiling water and aged for 17 years in the Madrid atmosphere, obtained immediately.

Figura 3. Micrografía obtenida con el MET de una película sellada después de 17 años de exposición en la atmósfera de Madrid, obtenida inmediatamente.

\section{DISCUSSION}

The starting hypothesis for the present work is the similitude between the transformations caused in anodic layers by the TEM electron beam in a few minutes, by artificial ageing for several hours in an oven at $100^{\circ} \mathrm{C}$, and by months and years of ageing at environmental temperature in natural atmospheric exposure stations ${ }^{[9]}$.

From the micrographs of the unsealed coating (Figs. 1a and 1b), the structural characteristics summarised in table I are deduced. Taking into account that $18 \%$ of the total volume corresponds to pores, in anodic films formed in sulphuric acid the $2.6 \mathrm{~g} / \mathrm{cm}^{3}$ of density attributed to them in the standard ${ }^{[10]}$ becomes 3.1 for the cell walls. As bayerite has a density of $2.4 \mathrm{~g} / \mathrm{cm}^{3}$, the pore must widen to a final diameter 1.41 times greater than its initial width. During the process a certain quantity of water is absorbed, which supposes approximately $12 \%$ of the total weight of the oxide, and this has a decisive influence on the changes that occur in the anodic films during ageing over many years ${ }^{[9]}$.

The incorporation of water during sealing enormously increases the reactivity of anodic layers to the effect of irradiation in the TEM, as is

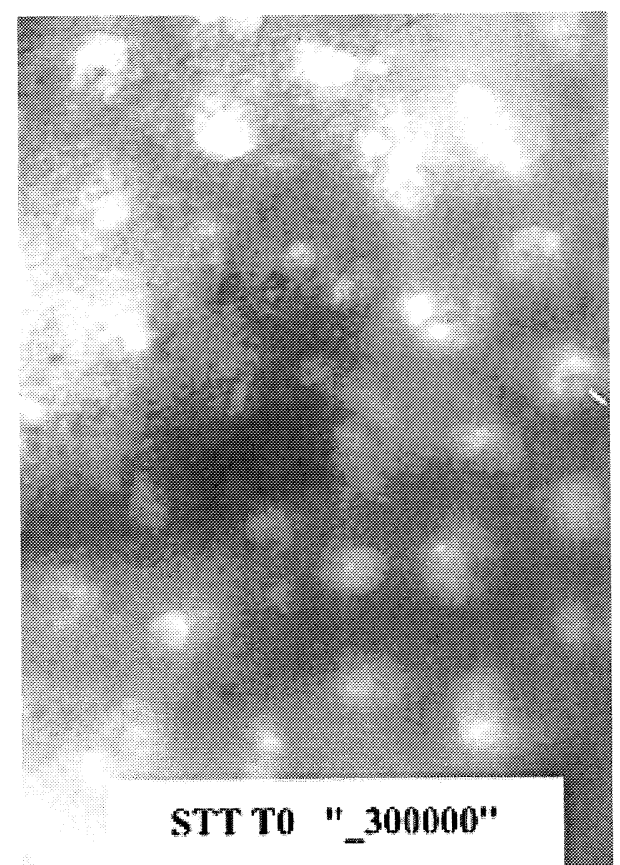

Figure 4. Micrograph of the structure of a film sealed for 45 min in boiling water and aged in an oven at $100^{\circ} \mathrm{C}$ for 24 h, obtained immediately.

Figura 4. Micrografía de la estructura del recubrimiento sellado 45 min en agua a ebullición y envejecida en estufa a $100^{\circ} \mathrm{C}$ durante $24 \mathrm{~h}$, obtenida inmediatamente.

deduced from simple observation of the series of micrographs in figures $1 \mathrm{a}, 1 \mathrm{~b}, 2 \mathrm{a}$ and $2 \mathrm{~b}$. Thompson et al. ${ }^{[1]}$ suggest that these changes in the substructure are favoured by anion contamination from the anodising bath, and probably related with drying, sintering or agglomeration and crystallisation processes. Other authors also attribute the changes observed to the elimination of the incorporated water, which is found in a greater proportion in the proximity of the pore ${ }^{[4]}$. Given the differences in behaviour between unsealed anodic films, with very little trapped water (Figs. 1a and 1b), and sealed anodic films, with $10-12 \%$ water (Figs. $2 \mathrm{a}$ and $2 \mathrm{~b}$ ), it seems evident that not all the incorporated water is eliminated, but that a considerable proportion gives rise to hydration reactions with the anhydrous alumina of the pore walls. This process is equivalent, in many aspects, to that which takes place during natural ageing in the atmosphere for very long times (Fig. 3). In this case the free water must react with the anhydrous alumina, causing the varieties of hydrated alumina to evolve towards thermodynamically stable varieties, as the substructure is very little modified by the effect of the electron beam. 

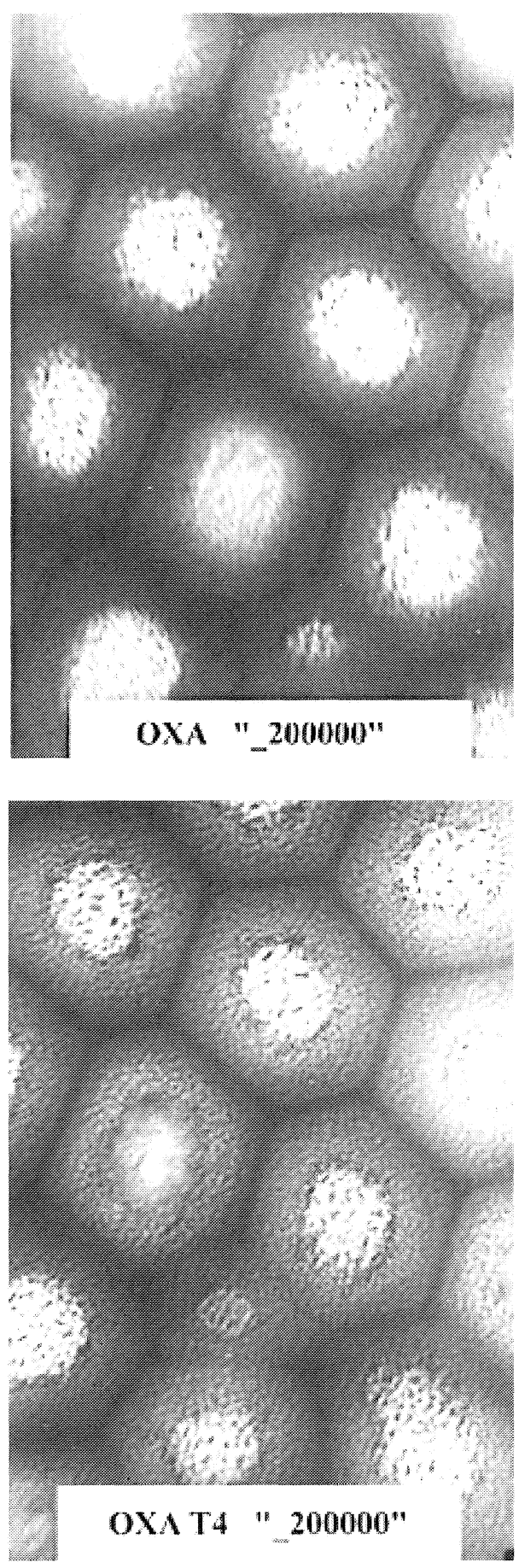

Figure 5. Micrographs of a film obtained in oxalic acid solution at $40 \mathrm{~V}$, for different electron beam exposure times: a) 0 min and b) 4 min.

Figura 5. Micrografías de una película obtenida en solución de ácido oxálico a $40 \mathrm{~V}$, para distintos tiempos de exposición al haz de electrones: a) 0 min y b) $4 \mathrm{~min}$.

The same effect of a few minutes exposure to the electron beam (Figs. $2 \mathrm{a}$ and $2 \mathrm{~b}$ ) or natural ageing for many years (Fig. 3) can be achieved by artificial ageing at a moderate temperature for several hours. This theory is confirmed by the similarity between the micrographs in figures 3 and

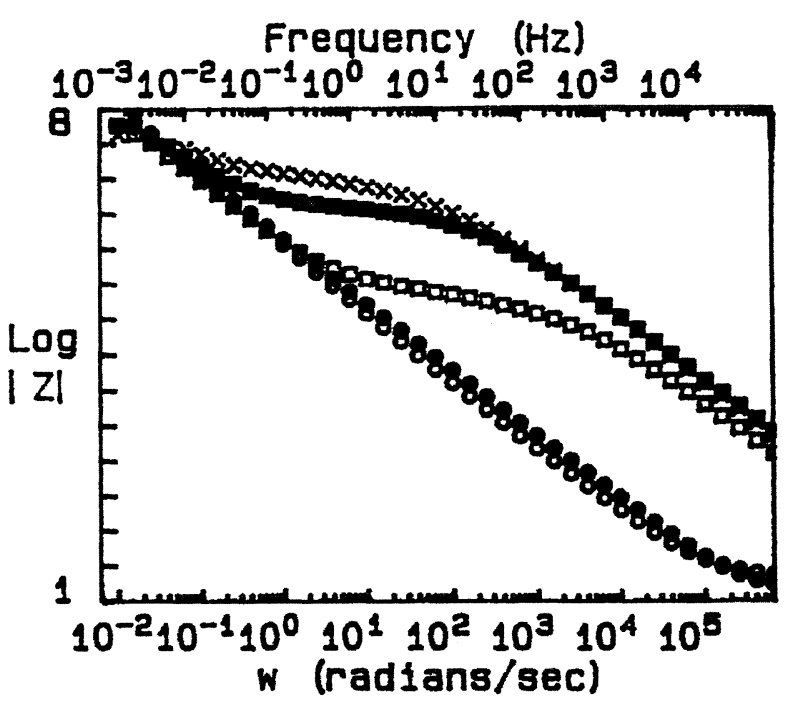

Figure 6. Impedance diagrams of: an unsealed anodic film before (O) and after (O) artificial ageing in an oven for 24 $\mathrm{h}$ at $100^{\circ} \mathrm{C}$; another anodic film, sealed for $45 \mathrm{~min}$ in boiling deionised water, before ( $\square$ ) and after ( $\square$ ) the same treatment; and a sealed anodic film aged in the Madrid atmosphere for 5 years $(x)$.

Figura 6. Diagramas de impedancia de un anodizado sin sellar antes (O) y después (O) de un envejecimiento artificial en estufa, de $24 \mathrm{~h}$ a $100^{\circ} \mathrm{C}$; de otro anodizado con un sellado de $45 \mathrm{~min}$ en agua desionizada a ebullición también antes ( $\mathbf{\square}$ ) y después ( $\mathbf{\square}$ ) del mismo tratamiento, y de un anodizado sellado y envejecido en la atmósfera de Madrid durante 5 años (x).

4, relating to films sealed for $45 \mathrm{~min}$ in boiling deionised water, after atmospheric ageing for 17 years in the former case and artificial ageing in an oven for $24 \mathrm{~h}$ at $100^{\circ} \mathrm{C}$ in the latter.

Similar processes also take place in films obtained in different anodising baths, as can be

Table I. Characteristics of the cells of anodic films formed in sulphuric and oxalic acid solutions

Tabla I. Características de las celdas de las películas anódicas formadas en soluciones de ácidos sulfúrico y oxálico

\begin{tabular}{lcccccc}
\hline PROCESS & $\Phi_{\mathrm{pi}}$ & $\mathrm{W}_{\mathrm{t}}$ & $\mathrm{C}_{\mathrm{s}}$ & $\mathrm{Sp}_{\mathrm{s}}$ & $\mathrm{V}_{\mathrm{p}}$ & $\Phi_{\mathrm{pf}}$ \\
& $\AA$ & $\AA$ & $\mathrm{cm}^{2}$ & $\mathrm{~m}^{2} / \mathrm{g}$ & $\%$ & $\AA$ \\
\hline Sulphuric acid & 225 & 225 & $1.75 \cdot 10^{-11}$ & 13.2 & 18 & $1.42 \Phi_{\mathrm{pi}}$ \\
Oxalic acid & 600 & 525 & $1.1 \cdot 10^{-10}$ & 6.35 & 26 & $1.55 \Phi_{\mathrm{pi}}$ \\
\hline
\end{tabular}

$\Phi_{\mathrm{pi}}$ - initial pore diameter

Wt - cell wall thickness

Cs - cell surface

Sps - specific surface

$\mathrm{Vp}$ - pore volume/anodic layer volume

$\Phi_{\mathrm{pf}}$ - final pore diameter 
seen in the micrographs in figures $5 \mathrm{a}$ and $5 \mathrm{~b}$, which correspond to 0 and 4 min exposure to the electron beam of an anodic film obtained in an oxalic acid bath. There is a clear differentiation between the cell walls contaminated with acid anions, and the limit bands of relatively pure alumina, with a lower reactivity of the latter $(1,4)$. A third phase can be added, constituted by the pore fill material, with nanoparticles of some $2-3 \mathrm{~nm}$ alternating with nanopores of a similar size (Fig. 5a).

The impedance spectra show that, at least in the case of anodic films obtained in sulphuric acid baths, the great structural changes found with TEM also enormously modify their electrical characteristics in ageing processes, as can be seen in the impedance diagrams in figure 6. Similar responses are reached in the oven at $100^{\circ} \mathrm{C}$ and in the atmosphere, in the former case in a matter of hours and in the latter case after years. Structural similarities in both cases are also evident, as can be verified with the TEM (Figs. 3 and 4).

All the above seems to indicate that the modifications produced under electron beam irradiation in the TEM allow the chemical and structural transformations that require years in natural ageing to be reproduced in a matter of minutes. The water retained in the anodic layers plays an essential role, as unsealed films are scarcely modified in the TEM (Figs. 1a and 1b), in the oven (Fig. 6), or in dry atmospheres that do not cause selfsealing. The impedance diagrams obtained initially and after years are the same, indicating that in the absence of water in the pores there is no ageing.

\section{CONCLUSIONS}

Water retained in the anodic layers favours the speed and importance of the transformations that take place under the TEM electron beam, in natural ageing in the atmosphere, or in artificial ageing at moderate temperatures.

There is an evident similarity between the structural and chemical transformations that take place in a few minutes under the effect of the electron beam, in a few hours in the oven at $100{ }^{\circ} \mathrm{C}$, and after months and years of exposure in the atmosphere at environmental temperature.

Unsealed anodic layers, practically free of water, do not show appreciable reactivity in any of the situations.

In the layers obtained in oxalic acid solutions there is a clear differentiation between the cell limit bands, of relatively pure alumina, which are hardly transformed by the irradiation, and the cell walls, of a lighter tone, which react much more intensely.

\section{Acknowledgements}

This work has been financed by the Interministerial Science and Technology Commission (CICYT) of the Ministry of Education and Culture (Project MAT98-096-C02-01).

\section{REFERENCES}

[1] G.E. Thompson, R.C. FurneauX and G.C. Wood, Corros. Sci. 18 (1978) 481-498.

[2] D. HÖNICKE, Aluminium 65 (1989) 1.154.

[3] R.C. Furneaux, G.E. Thompson and G.C. Wood, Corros. Sci. 18 (1992) 853-881.

[4] S. ONO and N. Masuko, Corros. Sci. 33 (1992) 503-507.

[5] G.C. WoOd and J.P. O'Sullivan, J. Electrochem. Soc. 116 (1969) 1351.

[6] K. Wada, T. Shiohira, M. Yamada and N. Baba, J. Mater. Sci. 21 (1986) 3.810.

[7] S. Wernick, S. Pinner and P. Sheasby, The surface treatments of aluminium and its lloys, 5 th ed., ASM International and Finishing Publications, Ohio, 1987, pp. 801-806.

[8] R. Lizarbe, V. López, E. Otero and J.A. GonzÁlez, Rev. Metal. Madrid 26 (1990) 359-367.

[9] R. Lizarbe, J.A. González, E. Otero and V. López, Aluminium 69 (1993) 548.

[10] UNE 38-012 standard. 